\title{
Studies on Chromated Erythrocytes. Effect of Sodium Chromate on Erythrocyte Glutathione Reductase *
}

\author{
George A. Koutras, Masao Hattori, Arthur S. Schneider, Frank G. \\ Ebaugh, JR., and William N. Valentine \\ (From the Department of Medicine, University of California at Los Angeles Center for the \\ Health Sciences, and the Laboratory Service, Wadsworth Hospital, Veterans Ad- \\ ministration Center, Los Angeles, Calif.; and the Department of Pathology, \\ Dartmouth Medical School, Hanover, N. H.)
}

The marked affinity of erythrocytes for hexavalent chromate anion was reported in 1950 by Gray and Sterling (1). Since then, erythrocytes labeled with radioactive sodium chromate have been used extensively for the determination of erythrocyte survival in vivo (1-5) and the determination of blood volume (4-6). The anionic hexavalent form of chromium is bound firmly to erythrocytes, is not reutilized, and is excreted mainly in the urine (2). Gray and Sterling suggested that the hexavalent form of chromium in the erythrocyte is probably bound to hemoglobin. Recent work, however, has shown that not all of the chromium is attached to hemoglobin, but that some of it is combined with a substance of low molecular weight, possibly glutathione (7).

Ebaugh, Emerson, and Ross (2) showed that small amounts of chromate, up to $9.5 \mu \mathrm{g}$ of chromium per $\mathrm{ml}$ of blood, had no apparent effect on the survival of erythrocytes in vivo. When $35 \mu \mathrm{g}$ per $\mathrm{ml}$ of blood was used, however, there was significant hemolysis in vivo during the first 24 hours. Donohue and associates (5) found that amounts below $25 \mu \mathrm{g}$ of chromium per $\mathrm{ml}$ of erythrocytes did not affect erythrocyte survival, but that larger amounts were toxic.

In this paper we report the results of studies of the effect of chromate on erythrocyte enzymes. A marked inhib:tion of glutathione-reductase (GSSG-R) activity was observed. Upon incubation with acetylphenylhydrazine, chromatetreated erythrocytes had an increased tendency to form Heinz bodies, and there was some decrease in glutathione stability.

* Submitted for publication August 28, 1963; accepted October 23, 1963.

This study was supported by grants from the U. S. Public Health Service and by contributions from the Leukemia Research Foundation, Los Angeles, Calif.

\section{Methods}

Materials. Human blood was obtained from healthy volunteers or patients with no hematologic abnormalities. Polyvinylpyrrolidone, Plasdone $\mathrm{C}(\mathrm{PVP})^{1}$; disodium EDTA, 3 times recrystallized ${ }^{2}$; Tris (Sigma 121), ADP, ATP, 6-phosphogluconate, ribose-5-phosphate, GSSG, and aldolase ${ }^{3}$; adenosine, glycylglycine, nicotinamide, and acetylcholine chloride 4 ; DPNH, TPN, TPNH, fructose-6-phosphate, DL-glyceraldehyde-3-phosphate, 3-phosphoglycerate, 2-phosphoglycerate, glucose-6phosphate, GSH, glucose-6-phosphate dehydrogenase (G-6-P-D), $\alpha$-glycerophosphate dehydrogenase, phosphoglycerate kinase, pyruvate kinase, lactic dehydrogenase, and triose phosphate isomerase ${ }^{5}$; fructose-1,6-diphosphate, phosphoenolpyruvate and enolase ${ }^{6}$; sodium chromate $\left(\mathrm{Na}_{2} \mathrm{CrO}_{4} \cdot 4 \mathrm{H}_{2} \mathrm{O}\right)$, chromium chloride $\left(\mathrm{CrCl}_{3} \cdot 6 \mathrm{H}_{2} \mathrm{O}\right)$, and triethanolamine $(\text { TEA })^{7}$; ascorbic acid ${ }^{8}$; hydrazine sulfate, iodoacetic acid, 2,4-dinitrophenylhydrazine, and acetylphenylhydrazine ${ }^{9}$; pyruvic acid ${ }^{10} ; 5,5^{\prime}$-dithiobis(2-nitrobenzoic acid) ${ }^{11}$; and ACD solution, Abbott special formula (132 mg dextrose, $250 \mathrm{mg}$ sodium citrate, $80 \mathrm{mg}$ citric acid, and $\mathrm{H}_{2} \mathrm{O} Q S$ to $\left.10 \mathrm{ml}\right)^{12}$ were obtained commercially. Deionized distilled water was used throughout all of the experiments.

Methods. Incubation of erythrocytes with chromium was carried out as described by Wintrobe (8) for cell labeling with modifications as follows: 4 vol of fresh blood was added to 1 vol of ACD solution. The supernatant ACD-plasma was discarded after centrifugation

\footnotetext{
1 Antara Chemicals, Los Angeles, Calif.

2 Alrose Chemical Co., Providence, R. I.

${ }^{3}$ Sigma Chemical Co., St. Louis, Mo.

4 California Corp. for Biochemical Research, Los Angeles, Calif.

5 C. F. Boehringer and Sons through California Corp. for Biochemical Research.

${ }^{6}$ Either C. F. Boehringer and Sons or Sigma Chemical Co.

${ }^{7}$ Van Waters and Rogers, Inc., Braun Division, Los Angeles, Calif.

8 Upjohn Co., Kalamazoo, Mich.

${ }^{9}$ Eastman Organic Chemicals, Rochester, N. Y.

${ }^{10}$ Schwarz Laboratories, New York, N. Y.

$11 \mathrm{~K}$. and $\mathrm{K}$. Laboratories, Jamaica, N. Y.

12 Abbott Laboratories, Oak Ridge, Tenn.
} 
for 10 minutes at $500 \times g$ at $4^{\circ} \mathrm{C}$ in an International model PR-2 refrigerated centrifuge. To the packed erythrocytes, sodium chromate was added in amounts varying from 1.0 to $100 \mu \mathrm{g}$ of elemental chromium per $\mathrm{ml}$ of original blood volume. The concentrations of chromate used throughout this paper are expressed as micrograms of elemental chromium per milliliter of original blood and not in terms of erythrocyte volume. The mixture was incubated in a water bath at $37^{\circ} \mathrm{C}$ for 45 minutes with frequent mixing. At the end of incubation ascorbic acid, $5 \mathrm{mg}$ per $\mathrm{ml}$ of initial blood volume, was added. The erythrocytes were washed 3 times with cold isotonic saline and were resuspended in isotonic saline to a concentration of approximately 3,000,000 erythrocytes per $\mu 1$. The erythrocytes were enumerated with the Coulter counter, model A. This erythrocyte-rich suspension was utilized for the various enzyme determinations. Except when otherwise noted, hemolysates prepared by lysis in distilled water followed by freezing and thawing were used for the determination of enzyme activities. Spectrophotometric assays were performed in a $3-\mathrm{ml}$ reaction volume in a silica cell of $1-\mathrm{cm}$ light path in a Beckman DU spectrophotometer ${ }^{13}$ coupled with a multiple sample absorbance recorder ${ }^{14}$ at $37^{\circ} \mathrm{C}$. All spectrophotometric assays other than the glyoxalase determination were performed at $340 \mathrm{~m} \mu$, and a molar extinction coefficient of $6.22 \times 10^{3}$ for DPNH and TPNH was employed in the calculations (9). Colorimetric determinations were performed in a Beckman model B spectrophotometer. ${ }^{13}$

Hexokinase was determined spectrophotometrically in a reaction mixture containing glycylglycine buffer, $\mathrm{pH}$ 8.1 (25 $\mu$ moles), nicotinamide (40 $\mu$ moles $), \mathrm{MgCl}_{2}$ (5 $\mu$ moles $)$, ATP $(5 \mu$ moles $)$, glucose $(5 \mu$ moles $)$, TPN (0.52 $\mu$ moles), G-6-P-D (0.8 enzyme units, EU), and hemolysate equivalent to $3.0 \times 10^{7}$ erythrocytes. An enzyme unit is the amount of enzyme required to utilize $1 \mu$ mole of substrate per minute.

Phosphoglucose isomerase was assayed by the change in absorbance at $340 \mathrm{~m} \mu$ in a system containing glycylglycine buffer, $\mathrm{pH} 8.1$ (25 $\mu$ moles), nicotinamide (40 $\mu$ moles), fructose-6-phosphate ( $5 \mu$ moles), TPN (0.52 $\mu$ moles $),$ G-6-P-D $(0.8 \mathrm{EU})$, and hemolysate equivalent to $3.0 \times 10^{8}$ erythrocytes.

Phosphofructokinase was determined in a $3.5-\mathrm{ml}$ reaction mixture containing Tris buffer, $\mathrm{pH} 8$ (200 $\mu$ moles), hydrazine sulfate ( $44 \mu$ moles), ATP ( $3 \mu$ moles), $\mathrm{MgCl}_{2}$ ( $3 \mu$ moles), fructose- 6 -phosphate $(5 \mu$ moles), aldolase $(1.0 \mathrm{EU})$, and hemolysate equivalent to $1.5 \times 10^{7}$ erythrocytes prepared by freezing and thawing in $0.1 \mathrm{M}$ phosphate buffer, $\mathrm{pH}$ 8.0. After 15 minutes at $37^{\circ} \mathrm{C}$ a trichloroacetic acid filtrate was assayed for triose (10).

Aldolase was assayed by a modification of the method of Sibley and Lehninger (10) in a $3.0-\mathrm{ml}$ reaction mixture containing TEA buffer, $\mathrm{pH} 8(50 \mu$ moles $)$, fructose-1,6-diphosphate (15 $\mu$ moles), hydrazine sulfate (44 $\mu$ moles), and hemolysate equivalent to $1.0 \times 10^{8}$ erythro-

13 Beckman Instruments, South Pasadena, Calif.

14 Gilford Instrument Laboratories, Oberlin, Ohio. cytes, prepared by mixing 1 part erythrocyte-rich suspension, 2 parts TEA buffer, and 6 parts normal saline, followed by freezing and thawing. After 30 minutes' incubation, triose production was measured in a trichloroacetic acid fitrate.

Triose phosphate isomerase was assayed by a modification of the spectrophotometric method of Beisenherz (11). The reaction mixture contained TEA buffer, $\mathrm{pH} 7.6$ (130 $\mu$ moles), DPNH $(0.5 \mu$ moles $)$, DL-glyceraldehyde-3-phosphate $(0.9 \mu$ moles $), \alpha$-glycerophosphate dehydrogenase ( 3.5 to $5.0 \mathrm{EU}$ ), and hemolysate equivalent to $1.0 \times 10^{6}$ erythrocytes.

Glyceraldehyde-3-phosphate dehydrogenase was assayed spectrophotometrically as described by Beisenherz and co-workers (12), adapted for hemolysate. The mixture contained TEA buffer, pH 7.6 (125 $\mu$ moles), 3-phosphoglycerate $(12 \mu$ moles $)$, ATP $(3.2 \mu$ moles $)$, EDTA, $\mathrm{pH} 7.6(0.5 \mathrm{mg}), \mathrm{MgSO}_{4}(24 \mu$ moles $), \mathrm{DPNH}(0.75$ $\mu$ moles), phosphoglycerate kinase ( $5 \mathrm{EU})$, and hemolysate equivalent to $6.0 \times 10^{8}$ erythrocytes.

Phosphoglycerate kinase activity was determined in a linked system utilizing pyruvate kinase. The method depends upon the conversion of ATP to ADP. The ADP thus generated is quantitated as limiting factor in the pyruvate kinase reaction. This method was developed in our laboratory to avoid interference by the large quantities of 2,3-diphosphoglycerate present in human erythrocytes and has proved very satisfactory. The system contained TEA buffer, $\mathrm{pH} 7.6$ (50 $\mu$ moles), $\mathrm{MgSO}_{4}(24 \mu$ moles $)$, ATP $(2 \mu$ moles $)$, phosphoenolpyruvate $(4.5 \mu$ moles $), \mathrm{KCl}(225 \mu$ moles $)$, iodoacetic acid (15 $\mu$ moles), DPNH (0.8 $\mu$ moles), pyruvate kinase (3.0 $\mathrm{EU})$, lactic dehydrogenase (16 EU), and hemolysate equivalent to $3.0 \times 10^{6}$ erythrocytes. The reaction was started with the addition of 3-phosphoglycerate (12 $\mu$ moles) and was followed at $340 \mathrm{~m} \mu$. The change in absorbance of a control without 3-phosphoglycerate was subtracted.

2,3-Phosphoglyceric mutase activity was measured by a modification of the spectrophotometric technique of Sutherland, Posternak, and Cori (13). The reaction system contained TEA buffer, $\mathrm{pH} 7.5$ (25 $\mu$ moles), $\mathrm{MgSO}_{4}(24 \mu$ moles $), \mathrm{KCl}(225 \mu$ moles $)$, ADP $(1.2$ $\mu$ moles), lactic dehydrogenase (18 EU), pyruvate kinase (0.5 EU), enolase (0.5 EU), DPNH (0.5 $\mu$ moles), 3 -phosphoglycerate ( $5 \mu$ moles), and hemolysate equivalent to $2.4 \times 10^{7}$ erythrocytes. The hemolysate was prepared by freezing and thawing a mixture of 1 part erythrocyte-rich suspension, 8 parts TEA buffer, and 16 parts saline.

Transketolase was assayed spectrophotometrically by following the conversion of ribose-5-phosphate to glyceraldehyde-3-phosphate in a linked system utilizing triose phosphate isomerase and $\alpha$-glycerophosphate dehydrogenase. The system contained TEA buffer, $\mathrm{pH} 7.6$ (135 $\mu$ moles), ribose-5-phosphate $(10 \mu$ moles $)$, DPNH $(0.375 \mu$ moles $)$, triose phosphate isomerase (180 to 250 EU), $\alpha$-glycerophosphate dehydrogenase (3.5 to 5.5 $\mathrm{EU})$, and hemolysate equivalent to $9.0 \times 10^{7}$ erythrocytes. The hemolysate was employed as the source of 
TABLE I

Effect of chromate on erythrocyte enzymes*

\begin{tabular}{|c|c|c|c|}
\hline & \multirow[b]{2}{*}{ Normal value } & \multicolumn{2}{|c|}{$\begin{array}{l}\text { Chromate concentration } \\
\text { ug chromium per ml blood }\end{array}$} \\
\hline & & $\mathbf{0}$ & 25 \\
\hline Hexokinase & $0.20-\quad 0.35$ & 0.230 & 0.210 \\
\hline Phosphoglucose isomerase & $6.9-21.0$ & 12.1 & 12.9 \\
\hline Phosphofructokinase & $5.5-11.0$ & 6.04 & 5.92 \\
\hline Aldolase & $1.0-1.4$ & 1.08 & 1.10 \\
\hline \multicolumn{4}{|l|}{ Glyceraldehyde-3-phos- } \\
\hline phate dehydrogenase & $24.0-32.0$ & 27.3 & 26.1 \\
\hline Triosephosphate isomerase & $180.0-230.0$ & 182.0 & 184.0 \\
\hline Phosphoglycerate kinase & $17.0-24.0$ & 18.7 & 18.5 \\
\hline \multicolumn{4}{|l|}{ 2,3-Phosphoglyceric } \\
\hline Enolase & $2.8-5.3$ & 5.10 & 5.35 \\
\hline Pyruvate kinase & $2.0-3.4$ & 2.69 & 2.65 \\
\hline Lactic dehydrogenase & $29.0-35.0$ & 33.4 & 32.4 \\
\hline \multicolumn{4}{|l|}{ Glucose-6-phosphate } \\
\hline \multicolumn{4}{|l|}{$\begin{array}{l}\text { dehydrogenase } \\
\text { 6-Phosphogluconic }\end{array}$} \\
\hline \multicolumn{4}{|l|}{ dehydrogenase } \\
\hline Glutathione reductase & $1.2-2.2$ & 1.94 & 0.40 \\
\hline Transketolase & $0.14-0.22$ & 0.123 & 0.115 \\
\hline Acetylcholinesterase & $90.0-110 \%$ & 102.0 & 96.7 \\
\hline Glyoxalase & $25.0-35.0$ & 31.8 & 32.9 \\
\hline
\end{tabular}

* Enzyme activity is expressed as micromoles of substrate utilized per minute per $10^{10}$ erythrocytes, except for acetylcholinesterase, which is expressed as percentage of normal, and glyoxalase, which is expressed as milligrams of methylglyoxal utilized per hour per $10^{10}$ erythrocytes. The first column represents the usual range of values in normal erythrocytes prepared by sedimentation in polyvinylpyrolidone citrate (21). The other columns represent enzyme activities of erythrocyte suspensions incubated with chromate as described in the text. The assay values of the chromated erythrocytes represent the mean of five samples of normal blood with the exception of the glyoxalase assays, which represent the mean of three samples.

thiamine pyrophosphate, phosphoribose isomerase, and phosphoketopentose epimerase, as well as of transketolase. The latter enzyme was the limiting factor in the reaction.

Pyruvate kinase, enolase, lactic dehydrogenase, G-6$P-D$, 6-phosphogluconic dehydrogenase, and acetylcholinesterase were performed as previously reported (14). Glutathione reductase was measured as described by Long and Carson (15) uti.izing stroma-containing hemolysate. Glyoxalase activity was assayed as previousiy reported (16).

After preincubation of erythrocytes with sodium chromate as described above, the washed erythrocytes were resuspended in various media for the following studies: Glutathione stability was determined on erythrocytes resuspended in heparinized plasma and in some

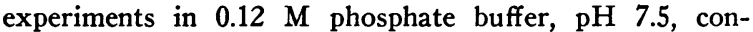
taining glucose $(2 \mathrm{mg}$ per $\mathrm{ml})$. The procedure was performed essentially as described by Beutler (17). GSH was measured by a slight modification of the 5,5'-dithiobis(2-nitrobenzoic acid) method of Beutler, Duron, and Kelly (18). Autohemolysis was determined as previousiy described (14) after reconstitution of the chromated erythrocytes in defibrinated serum. Erythrocyte osmotic fragility as described by Dacie (19) was performed on the chromated erythrocytes of the erythrocyte-rich suspensions prepared as noted above. The Heinz body studies were performed in heparinized plasma. Packed erythrocytes separated by centrifugation were resuspended to a $40 \%$ packed cell volume in $0.15 \mathrm{M} \mathrm{NaCl}$ containing sufficient glucose to result in a final concentration of $3 \mathrm{mg}$ per $\mathrm{ml}$. This suspension was incubated for 45 minutes at $37^{\circ} \mathrm{C}$ with varying concentrations of sodium chromate. After incubation the erythrocytes were washed with $0.15 \mathrm{M} \mathrm{NaCl}$ and were suspended to a $50 \%$ packed cell volume in the original heparinized plasma. Heinz body formation on incubation with acetylphenylhydrazine was quantitated essentially as described by Beutler, Dern, and Alving (20). The incubations were observed for Heinz body formation after 1, 2, and 4 hours.

\section{Results}

\section{Effect of hexavalent chromate anion on erythro- cyte enzymes}

The effects of preincubation with chromate on erythrocyte enzymes are summarized in Table I. In general no major deviations from normal were noted. When GSSG-R was assayed, however, there was a significant reduction in its activity. Progressive reduction of GSSG-R activity was noted with increasing concentrations of chromate 


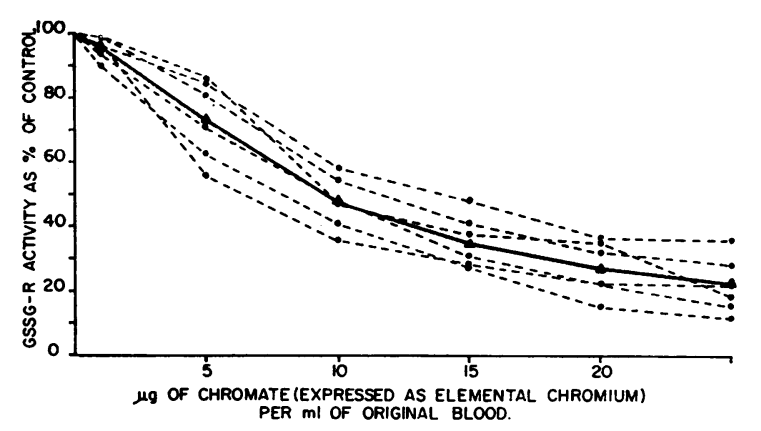

Fig. 1. EfFect of incubation with Chromate on ERYTHROCYTE GLUTATHIONE-REDUCTASE (GSSG-R) ACTIVITY. Each line represents the relation of concentration of chromate to the GSSG-R activity in each of six separate samples. The solid line represents the mean values. Results are expressed in terms of percentage of the sample to which no chromate was added.

up to $50 \mu \mathrm{g}$ of chromate (expressed as elemental chromium) per $\mathrm{ml}$ of original blood (Figures 1 and 2). Further additions beyond this concentration resulted in little or no further reduction in enzyme activity. At $37^{\circ} \mathrm{C}$ the reduction in activity occurred within the first 5 minutes of incubation, and little further reduction was observed with longer incubations. Some visible hemolysis was noted when chromate concentrations in excess of 15 to $20 \mu \mathrm{g}$ per $\mathrm{ml}$ were used. The $\mathrm{pH}$ of the incubating media varied from 6.5 to 6.7. No significant changes in $\mathrm{pH}$ occurred after the addition of sodium chromate or ascorbic acid. Absorption spectra of the chromated suspensions ( $25 \mu \mathrm{g}$ chromium per $\mathrm{ml}$ of blood) failed to reveal peaks at $618 \mathrm{~m} \mu$ or $630 \mathrm{~m} \mu$ indicative of sulfhemoglobin or methemoglobin formation.
TABLE II

Prevention of chromate inhibition of glutathione reductase $(G S S G-R)$ with ascorbic acid

\begin{tabular}{ccc}
\hline & \multicolumn{2}{c}{ GSSG-R activity* } \\
$\begin{array}{c}\text { Chromate } \\
\text { concentration }\end{array}$ & $\begin{array}{c}\text { Ascorbic acid } \\
\text { added before } \\
\text { incubation } \\
\text { with sodium } \\
\text { chromate }\end{array}$ & $\begin{array}{c}\text { Ascorbic acid } \\
\text { added atter } \\
\text { incubation } \\
\text { with sodium } \\
\text { chromate }\end{array}$ \\
\hline$\mu g$ Cr per ml blood & 1.9 & 1.9 \\
0 & 1.8 & 0.93 \\
10 & 1.8 & 0.61
\end{tabular}

* GSSG-R activity is expressed as micromoles of substrate utilized per minute per $10^{10}$ erythrocytes.

Although ascorbic acid was utilized as a simple reducing agent, it might have influenced the GSSG-R inhibition in a more active fashion, possibly through stimulation of the pentose phosphate pathway. No significant differences in inhibition were observed, however, when ascorbic acid was omitted from the suspensions.

\section{Effect of trivalent chromic cation on erythrocyte enzymes}

The effect of trivalent chromic cation is shown in Figure 2. There was essentially no effect on GSSG-R activity even when very large amounts ( $100 \mu \mathrm{g}$ of $\mathrm{Cr}$ per $\mathrm{ml}$ of blood) were used. Also, the chromate effect was abolished when ascorbic acid was added to the suspension before incubation with chromate (Table II). Ascorbic acid is routinely employed in erythrocyte-labeling techniques to reduce chromium from the hexavalent chromate to the trivalent chromic form.

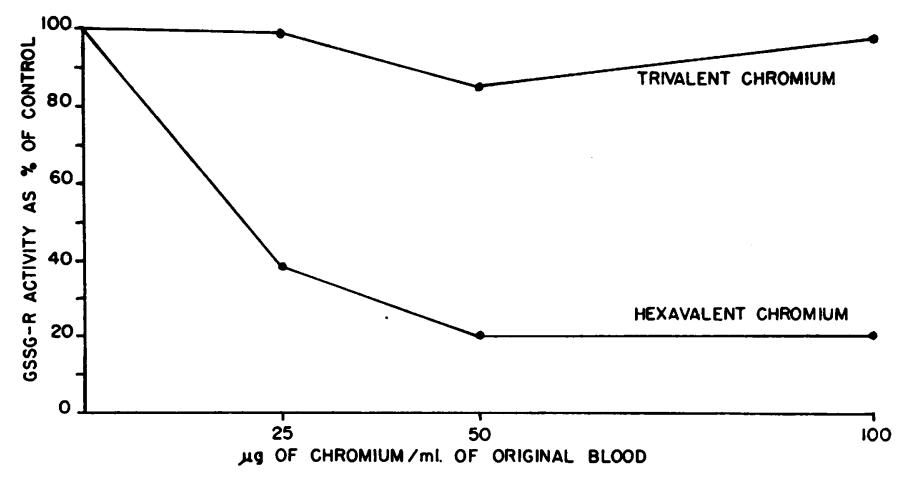

Fig. 2. CoMparison of EFFECT OF HeXavalent AND TRIVALENT CHROMIUM ON ERYTHROCYTE GLUTATHIONE-REDUCTASE (GSSG-R) ACTIVITY. 

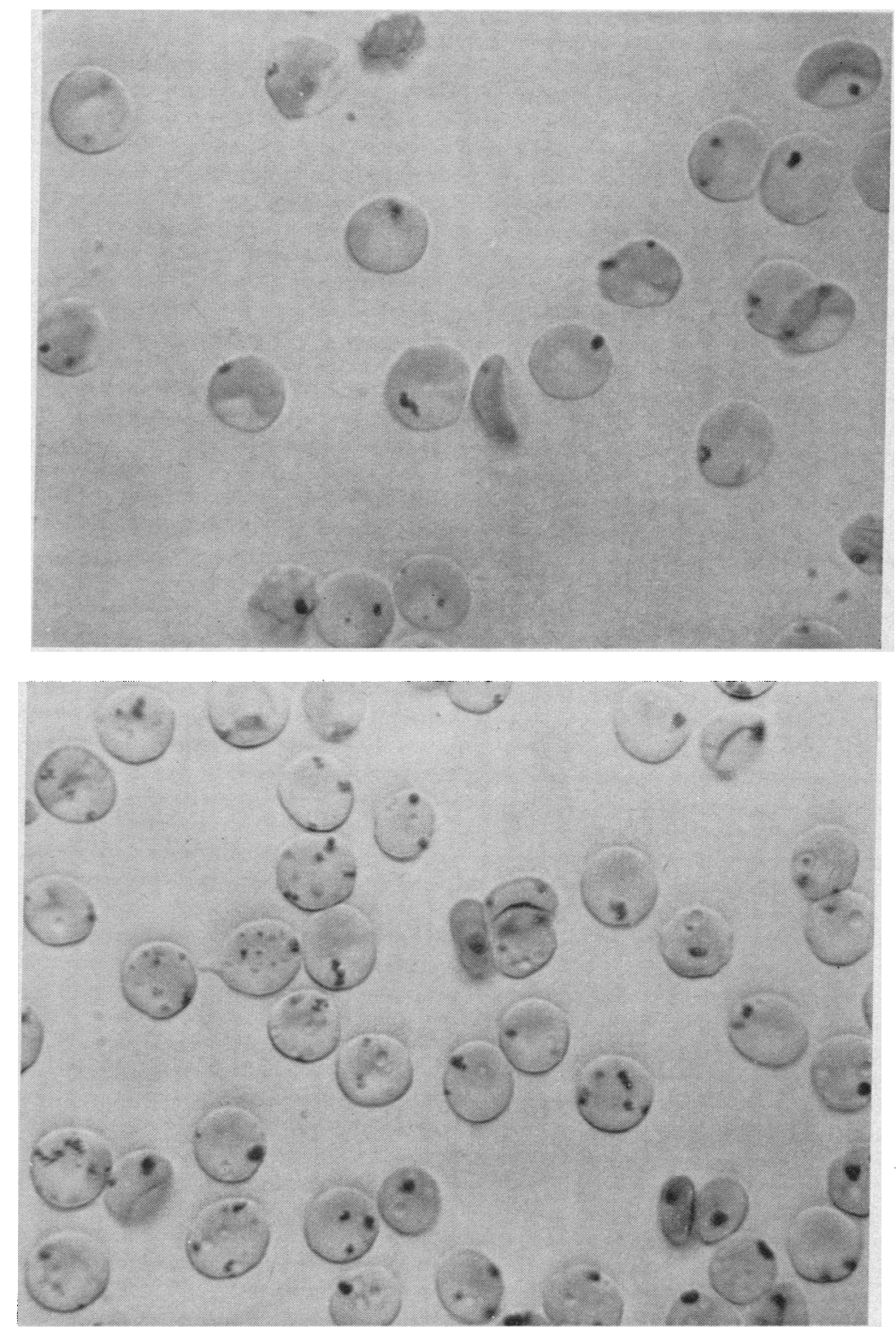

Fig. 3. ACETylphenylhydRazine-induced Heinz bodies in ChromateTREATED ERYTHROCYTES. Photomicrograph of wet preparation of erythrocytes stained supravitally with crystal violet. The upper plate represents sample incubated without the addition of chromate. The lower plate represents erythrocytes preincubated with $25 \mu \mathrm{g}$ of chromate (expressed as elemental chromium) per $\mathrm{ml}$ of original blood. Conditions are as described in text.

\section{Effect of chromate in hemolysates}

Because of the observation that GSSG-R inhibition employing intact erythrocytes was associated only with chromium in the hexavalent form, studies were performed with hemolysates (pre- pared by freezing and thawing) to determine whether the differences were due to inability of the trivalent chromium to enter the intact erythrocyte. Chromate produced a fall in GSSG-R activity of $40 \%$ with $10 \mu \mathrm{g}$ of chromium per $\mathrm{ml}$ of original 


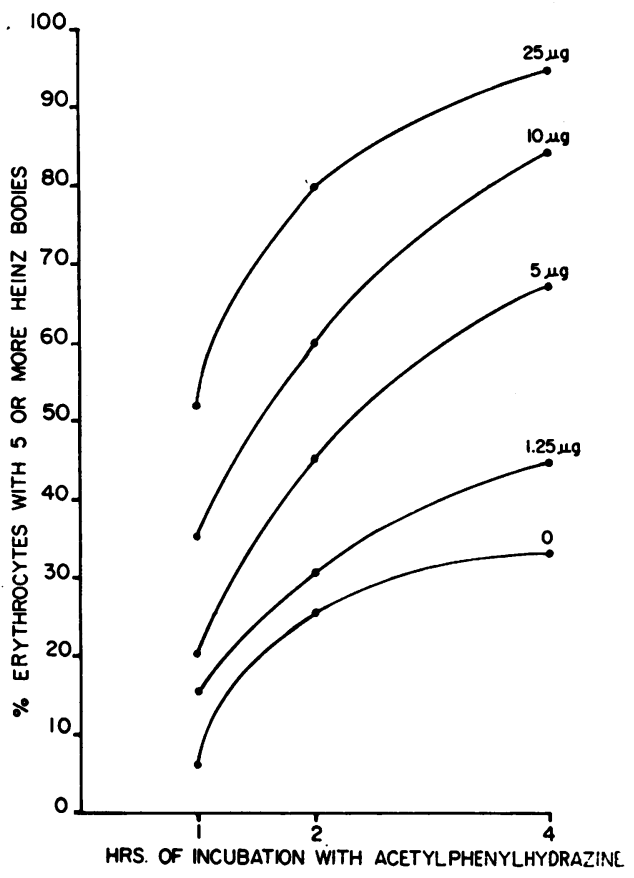

Fig. 4. Heinz body formation on incubation with ACETYLPHENYLHYDRAZINE : EFFECT OF PREINCUBATION WITH CHROMATE. The conditions are described in the text. Each curve represents a sample preincubated with a different concentration of chromate. The concentration of chromate is expressed as micrograms of chromium per milliliter of original blood.

blood, $60 \%$ with $25 \mu \mathrm{g}$ per $\mathrm{ml}$, and $84 \%$ when $100 \mu \mathrm{g}$ per $\mathrm{ml}$ of blood was added to the hemolysate followed by a 45-minute incubation. In contrast, only $3 \%$ inhibition was observed when trivalent chromium (100 $\mu \mathrm{g}$ chromium per $\mathrm{ml}$ of blood, final concentration $2 \times 10^{-3} \mathrm{M}$ ) was used. Hexavalent but not trivalent chromium caused reduction of GSSG-R activity in hemolysates. This difference was observed in the presence or absence of EDTA in the final assay system.

\section{Effect of chromate-induced GSSG-R deficiency}

Heinz body formation. Chromate-treated erythrocytes had an increased tendency to form Heinz bodies when incubated with acetylphenylhydrazine (Figure 3). The effects of increasing concentrations of chromate are shown in Figure 4. Heinz body formation increased with increasing concentrations of chromate, and an earlier appearance of Heinz bodies was observed with higher concentrations of chromate. Incubation of erythrocytes with sodium chromate in the absence of acetylphenylhydrazine failed to produce Heinz bodies.

Glutathione stability. Incubation with $25 \mu \mathrm{g}$ of sodium chromate per $\mathrm{ml}$ of original blood volume was associated with a modest decrease in erythrocyte GSH concentration (Table III). Some reduction in GSH concentration was generally noted on incubation with lesser amounts of chromate as well, but the results were inconsistent. Washing and resuspension of the erythrocytes in heparinized plasma were also irregularly associated with some decrease in erythrocyte GSH. When acetylphenylhydrazine was added to the incubation system, however, a definite further decrease in GSH concentration was observed (Table IV). Similar results were obtained when GSH stability was followed in a glucose-containing phosphate buffer. The control samples incubated for 2 hours without acetylphenylhydrazine show what are perhaps significant differences in the degree of change in the GSH concentration in the samples exposed to 0 and $25 \mu \mathrm{g}$ of chromium per $\mathrm{ml}$ of blood. The samples incubated without chromate show a rather uniform decrease varying from 59 to $92 \mu \mathrm{g}$ of GSH. The samples exposed to chromate show a somewhat variable apparent resistance to fall of the erythrocyte GSH. We have no explanation for this interesting phenomenon.

Fragility and autohemolysis. No change in os-

TABLE III

Effect of chromate on erythrocyte GSH*

\begin{tabular}{cccc}
\hline \hline & \multicolumn{2}{c}{$\begin{array}{c}\text { Chromate concentration } \\
\text { ug chromium per ml blood }\end{array}$} \\
\cline { 2 - 3 } Sample & 0 & 25 & $\Delta$ GSH \\
\hline & & & $\mu g$ \\
1 & 618 & 557 & -61 \\
2 & 549 & 464 & -85 \\
3 & 612 & 513 & -99 \\
4 & 628 & 475 & -153 \\
5 & 764 & 680 & -84 \\
6 & 487 & 437 & -50 \\
7 & 683 & 643 & -40 \\
8 & 622 & 434 & -188 \\
9 & 686 & 566 & -120 \\
10 & 479 & 414 & -65 \\
& & &
\end{tabular}

* GSH concentration was measured after a 45-minute incubation with chromate as described in text. GSH is expressed as micrograms per $10^{10}$ erythrocytes. The third column shows the decrease in GSH after incubation with $25 \mu \mathrm{g}$ of chromium per $\mathrm{ml}$ of blood. 
TABLE IV

Glutathione stability of chromate-treated erythrocytes*

\begin{tabular}{|c|c|c|c|c|c|c|c|c|c|c|}
\hline \multirow{2}{*}{$\begin{array}{l}\text { Sample } \\
\text { Chromate concentration, } \\
\quad \mu g \mathrm{Cr} \text { per ml blood }\end{array}$} & \multicolumn{2}{|c|}{1} & \multicolumn{2}{|c|}{2} & \multicolumn{2}{|c|}{3} & \multicolumn{2}{|c|}{4} & \multicolumn{2}{|c|}{5} \\
\hline & 0 & 25 & 0 & 25 & 0 & 25 & 0 & 25 & 0 & 25 \\
\hline \multirow{4}{*}{$\begin{array}{l}\text { GSH } \mu \mathrm{g} / 10^{10} \text { erythrocytes } \\
\text { Initial (after washing) } \\
\text { Incubation, } 2 \mathrm{hr} \\
\text { Incubation, } 2 \mathrm{hr} \text {, with } \\
\text { acetylphenylhydrazine }\end{array}$} & & & & & & & & & & \\
\hline & 686 & 566 & 643 & 593 & 642 & 556 & 622 & 434 & 479 & 413 \\
\hline & 600 & 593 & 551 & 557 & 558 & 550 & 556 & 483 & 420 & 422 \\
\hline & 473 & 368 & 459 & 306 & 466 & 238 & 491 & 301 & 313 & 208 \\
\hline Decrease, $\%$ & 21.2 & 39.7 & 16.7 & 45.2 & 16.4 & 56.8 & 11.7 & 37.5 & 25.5 & 50.7 \\
\hline
\end{tabular}

* Erythrocytes were incubated with chromate as described in text, washed, and resuspended to a packed cell volume of $50 \%$. Sample 1 was resuspended in heparinized plasma; samples 2 to 5 were resuspended in phosphate buffer, $0.12 \mathrm{M}$, $\mathrm{pH} 7.5$, containing glucose, $2 \mathrm{mg}$ per $\mathrm{ml}$. The percentage of decrease after incubation with acetylphenylhydrazine, $5 \mathrm{mg}$ per $\mathrm{ml}$ of blood, is expressed in terms of the control incubated for 2 hours without acetylphenylhydrazine.

motic fragility was noted in suspensions incubated with $10 \mu \mathrm{g}$ of chromium per $\mathrm{ml}$ of blood, washed and reconstituted as described under Methods. Also no increase beyond normal in autohemolysis after 48 hours was observed in the chromate-treated blood reconstituted under sterile conditions with defibrinated serum.

\section{Discussion}

The data presented show that incubation of human erythrocytes with sodium chromate in quantities of 5 to $25 \mu \mathrm{g}$ of chromium per $\mathrm{ml}$ of whole blood inhibits the activity of erythrocyte GSSG-R. The degree of inhibition is greater as the concentration of chromate is increased, a reduction to about $20 \%$ of the original activity being observed at concentrations of $25 \mu \mathrm{g}$ of chromium per $\mathrm{ml}$ of blood. Concentrations up to this amount have been considered nontoxic to erythrocytes and compatible with erythrocyte-labeling studies. The present availability of $\mathrm{Cr}^{51}$ of high specific activity has made the use of such concentrations of chromate rather unusual. Present day techniques generally employ chromate concentrations of less than $0.1 \mu \mathrm{g}$ of chromium per $\mathrm{ml}$ of blood.

The deficiency of GSSG-R induced by sodium chromate may be the cause of the rapid disappearance in vivo of erythrocytes stored for 14 days in ACD noted by Ebaugh, Emerson, and Ross (2), and Donohue and co-workers (5), employing concentrations of chromate above 35 or $50 \mu \mathrm{g}$ of chromium per $\mathrm{ml}$ of blood. Concentrations of chromate in this range are regularly associated with an inhibition of GSSG-R activity to levels approximately $20 \%$ of normal. Quantitatively similar decreases in activity of GSSG-R have been described by Löhr and Waller (22) in two patients with congenital nonspherocytic hemolytic anemia. One of these patients with erythrocyte GSSG-R activity of $16 \%$ of normal had an erythrocyte $\mathrm{Cr}^{51}$ apparent half-life of 7 days. Carson, Brewer, and Ickes (23) reported a patient with a $43 \%$ decrease of GSSG-R whose $\mathrm{Cr}^{51}$ erythrocyte survival was normal, and hemolytic anemia was not apparent until the patient was challenged with primaquine or similar drugs. This reduction in activity is similar in degree to that which can be induced by incubation of erythrocytes with sodium chromate in concentrations of 5 to $10 \mu \mathrm{g}$ of chromium per $\mathrm{ml}$ of blood. Such incubations have not been reported to shorten erythrocyte survival in vivo.

The mechanism of GSSG-R inhibition by sodium chromate has not yet been elucidated. Only the hexavalent form of chromium is inhibitory, even in hemolysates, and it is possible that the enzyme inhibition is linked to the reduction of chromate. Chromate inhibition occurs in intact cells, whole hemolysate, and stroma-free hemolysate. Also the inhibition is not due to a direct oxidant effect of chromated hemolysate on GSH in the final assay system, since by direct measurement GSH is no less stable in the presence of chromated hemolysate in such incubations than in the presence of hemolysate not treated with chromate.

The mechanisms of cell damage in spontaneous and chromate-induced GSSG-R deficiencies are not clear. It is unlikely that a resultant GSH de- 
ficiency alone can cause major shortening of erythrocyte survival since almost complete selective inhibition of intracellular erythrocyte GSH with $N$-ethylmaleimide does not seriously impair erythrocyte survival (24). Also, a hereditary absence of GSH is associated with only a mild hemolytic state (25).

Erythrocyte GSH concentration was decreased in the three cases $(23,24)$ cited above. Only a modest decrease in GSH was noted in chromateinduced GSSG-R deficiency. This may be due to the fact that GSH was measured only after short incubations in the absence of known oxidative stress. A rapid fall in GSH was noted after incubation with acetylphenyihydrazine. Because of the marked loss in activity of GSSG-R, this GSH instability was anticipated. GSH stability was not altered in the patient reported by Carson and co-workers (23) with a $43 \%$ decrease in GSSG-R activity, but was abnormal in one of the patients reported by Löhr and Waller (22) with a more severe enzyme deficit.

The mechanism of Heinz body formation is possibly similar to that which occurs in G-6-P-D deficiency. Jandl (26) has recently suggested that Heinz body formation in congenital G-6-P-D and GSSG-R deficiencies is related to inability of these cells to protect hemoglobin by primary oxidation of cellular constituents with lower oxidation potentials such as glutathione.

\section{Summary}

The effect of sodium chromate on the activities of human erythrocyte enzymes was studied. There was no effect on the activities of the enzymes of the glycolytic pathway, on those of the pentosephosphate pathway which were studied, or of acetylcholinesterase and glyoxalase. Concentrations of chromate of 5 to $25 \mu \mathrm{g}$ of chromium per $\mathrm{ml}$ of blood produced major inhibition of erythrocyte glutathione reductase. The inhibition was induced by hexavalent chromate anion only, even in hemolysates. Trivalent chromic cation had no inhibitory effect. The inhibition was associated with increased sensitivity to acetylphenylhydrazine manifested as Heinz body formation and GSH instability. No effect on osmotic fragility or on autohemolysis was observed.

\section{Acknowledgments}

The technical assistance of Mr. K. Kurschner, Miss M. Mattson, Miss M. Schlumpf, Miss M. L. Wilson, and Mrs. J. Wittenberg is gratefully acknowledged.

\section{References}

1. Gray, S. J., and K. Sterling. The tagging of red cells and plasma proteins with radioactive chromium. J. clin. Invest. 1950, 29, 1604.

2. Ebaugh, F. G., Jr., C. P. Emerson, and J. F. Ross. The use of radioactive chromium 51 as an erythrocyte tagging agent for the determination of red cell survival in vivo. J. clin. Invest. 1953, 32, 1260.

3. Necheles, T. F., I. M. Weinstein, and G. V. LeRoy. Radioactive sodium chromate for the study of survival of red blood cells. I. The effect of radioactive sodium chromate on red cells. J. Lab. clin. Med. 1953, 42, 358.

4. Mollison, P. L., and N. Veall. The use of the isotope ${ }^{\text {s1 }} \mathrm{Cr}$ as a label for red cells. Brit. J. Haemat. 1955, 1, 62.

5. Donohue, D. M., A. G. Motulsky, E. R. Giblett, G. Pirzio-Biroli, V. Viranuvatti, and C. A. Finch. The use of chromium as a red-cell tag. Brit. J. Haemat. 1955, 1, 249.

6. Sterling, K., and S. J. Gray. Determination of the circulating red cell volume in man by radioactive chromium. J. clin. Invest. 1950, 29, 1614.

7. Prins, H. K. The binding of ${ }^{51} \mathrm{Cr}$ by human erythrocytes. Vox Sang. (Basel) 1962, 7, 370.

8. Wintrobe, M. M. Clinical Hematology, 5th ed. Philadelphia, Lea \& Febiger, 1962, p. 164.

9. Horecker, B. L., and A. Kornberg. The extinction coefficients of the reduced band of pyridine nucleotides. J. biol. Chem. 1948, 175, 385.

10. Sibley, J. A., and A. L. Lehninger. Determination of aldolase in animal tissues. J. biol. Chem. 1949, 177, 859.

11. Beisenherz, G. Triosephosphate isomerase from calf muscle in Methods in Enzymology, S. P. Colowick and N. O. Kaplan, Eds. New York, Academic Press, 1955, vol. 1, p. 387.

12. Beisenherz, G., H. J. Boltze, Th. Bücher, R. Czok, K. H. Garbade, E. Meyer-Arendt, and G. Pfleiderer. Diphosphofructose-Aldolase, PhosphoglyceraldehydDehydrogenase, Milchsäure-Dehydrogenase, Glycerophosphat-Dehydrogenase und Pyruvat Kinase aus Kaninchenmuskulatur in einem Arbeitsgang. Z. Naturforsch. [B] 1953, 8b, 555.

13. Sutherland, E. W., T. Posternak, and C. F. Cori Mechanism of the phosphoglyceric mutase reaction. J. biol. Chem. 1949, 181, 153.

14. Tanaka, K. R., W. N. Valentine, and S. Miwa. Pyruvate kinase $(\mathrm{PK})$ deficiency in hereditary nonspherocytic hemolytic anemia. Blood 1962, 19, 267. 
15. Long, W. K., and P. E. Carson. Increased erythrocyte glutathione reductase activity in diabetes mellitus. Biochem. biophys. Res. Commun. 1961, 5, 394.

16. Valentine, W. N., and K. R. Tanaka. The glyoxalase content of human erythrocytes and leukocytes. Acta Haemat. 1961, 26, 303.

17. Beutler, E. The glutathione instability of drug-sensitive red cells. A new method for the in vitro detection of drug sensitivity. J. Lab. clin. Med. 1957, 49, 84.

18. Beutler, E., O. Duron, and B. M. Kelly. Improved method for the determination of blood glutathione. J. Lab. clin. Med. 1963, 61, 882.

19. Dacie, J. V. The Haemolytic Anemias. New York, Grune \& Stratton, 1954, p. 478.

20. Beutler, E., R. J. Dern, and A. S. Alving. The hemolytic effect of primaquine. VI. An in vitro test for sensitivity of erythrocytes to primaquine. $J$. Lab. clin. Med. 1955, 45, 40.
21. Valentine, W. N., K. R. Tanaka, and R. E. Fredricks. Erythrocyte acid phosphatase in health and disease. Amer. J. clin. Path. 1961, 36, 328.

22. Löhr, G. W., and H. D. Waller. Eine neue enzymopenische hämolytische Anämie mit Glutathionreduktase-Mangel. Med. Klin. 1962, 57, 1521.

23. Carson, P. E., G. J. Brewer, and C. Ickes. Decreased glutathione reductase with susceptibility to hemolysis (abstract). J. Lab. clin. Med. 1961, 58, 804.

24. Jacob, H. S., and J. H. Jandl. Effects of sulfhydryl inhibition on red blood cells. II. Studies in vivo. J. clin. Invest. 1962, 41, 1514.

25. Oort, M., J. A. Loos, and H. K. Prins. Hereditary absence of reduced glutathione in the erythrocytes-a new clinical and biochemical entity? Vox Sang. (Basel) 1961, 6, 370.

26. Jandl, J. H. The Heinz body hemolytic anemias. Ann. intern. Med. 1963, 58, 702. 